\title{
Energy and protein requirements of crossbred cattle in feedlot
}

\section{Exigências energéticas e proteicas de bovinos mestiços em confinamento}

\author{
Maria Luciana Menezes Wanderley Neves ${ }^{1 *}$; Antonia Sherlânea Chaves Véras ${ }^{2}$; \\ Evaristo Jorge Oliveira de Souza ${ }^{3}$; Marcelo de Andrade Ferreira ${ }^{2}$; \\ Sebastião de Campos Valadares Filho ${ }^{4}$; Gabriel Santana da Silva ${ }^{5}$; \\ Francisco Fernando Ramos de Carvalho²; Diogo José Gomes de Oliveira ${ }^{6}$; \\ Edine Roberta de Lima ${ }^{6}$; Ligia Maria Gomes Barreto ${ }^{7}$
}

\begin{abstract}
The objective of this study is to predict the energy and protein requirements of crossbred dairy cattle in feedlot. The study was conducted at the Unidade Acadêmica de Serra Talhada, Universidade Federal Rural de Pernambuco, Brazil with 30 bulls with a body weight of $339.1 \pm 35.4 \mathrm{~kg}$. Five animals were slaughtered at the end of the adaptation period to serve as the reference group; the remainder of the animals was slaughtered after 112 days. The latter group was randomly allocated to receive five treatments: $0,17,34,51$ and $68 \%$ of concentrate in the feed using a completely randomized design. The dietary intake of the animals that were not given concentrate was restricted to $1.5 \%$ of their body weight; these animals composed the group fed for maintenance. The body composition and empty body weight (EBW) were estimated by means of the comparative slaughter method and full dissection of a half-carcass. The results showed that for crossbred dairy bulls in confinement, the net and metabolizable energy requirements were 86.49 and $138 \mathrm{kcal} \mathrm{EBW}^{-0.75} \mathrm{day}^{-1}$, respectively, and the efficiency of use of metabolizable energy for maintenance and gain were $62.67 \%$ and $31.67 \%$, respectively. The net energy $\left(\mathrm{NE}_{\mathrm{g}}\right)$ and net protein $\left(\mathrm{NP}_{\mathrm{g}}\right)$ requirements for gain can be estimated using

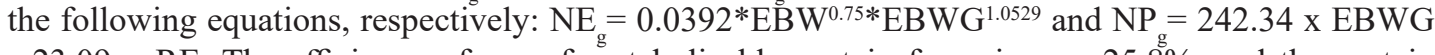
- 23.09 x RE. The efficiency of use of metabolizable protein for gain was $25.8 \%$, and the protein requirement for maintenance was $2.96 \mathrm{~g} \mathrm{EBW}^{-0.75}$ day $^{-1}$. The rumen degradable protein can supply $62.44 \%$ of the crude protein requirements of feedlot dairy crossbred bulls with a body weight of 450 $\mathrm{kg}$ while gaining $1 \mathrm{~kg}$ day $^{-1}$.
\end{abstract}

Key words: Body composition. Maintenance. Weight gain.

${ }^{1} \mathrm{Dr}^{\mathrm{a}}$ em Zootecnia, bolsista PDJ/CNPq, Universidade Federal Rural de Pernambuco, UFRPE, Recife, Pernambuco PE, Brasil. E-mail: luciana.veterinaria@gmail.com

2 Profs., Drs. em Zootecnia, Dept ${ }^{\circ}$ de Zootecnia, UFRPE, Recife, PE, Brasil. E-mail: antonia.veras@ufrpe.br; marcelo.aferreira@ ufrpe.br; ffrcarvalho@gmail.com

${ }^{3}$ Prof., Dr., em Zootecnia, Unidade Acadêmica de Serra Talhada, UAST, UFRPE, Serra Talhada, PE, Brasil. E-mail: evaristojorge@ gmail.com

${ }^{4}$ Prof., Dr. em Zootecnia, Dept ${ }^{\text {}}$ de Zootecnia, Universidade Federal de Viçosa, UFV, Viçosa, MG, Brasil. E-mail: scvfilho@ufv.br

${ }_{5}^{5}$ M.e em Zootecnia, UFRPE, Recife, PE, Brasil. E-mail: gabrielsantanas@hotmail.com

${ }^{6}$ Discentes de Graduação em Zootecnia, UAST/UFRPE, Serra Talhada, PE, Brasil. E-mail: diogo.oliveira.21@hotmail.com; edinezootecnia@gmail.com

${ }^{7} \mathrm{Dr}^{\mathrm{a}}$ em Zootecnia, Bolsista PNPD/CAPES, UFRPE, Recife, PE, Brasil. E-mail: ligiamgbarreto@gmail.com

* Author for correspondence 


\section{Resumo}

Com o objetivo de predizer as exigências energéticas e proteicas de bovinos mestiços leiteiros em confinamento, este trabalho foi conduzido na Unidade Acadêmica de Serra Talhada da Universidade Federal Rural de Pernambuco. Foram utilizados 30 machos não castrados, com peso corporal inicial de $339,1 \pm 35,4 \mathrm{~kg}$. Cinco animais foram abatidos após período de adaptação, compondo o grupo referência, e o restante foi abatido após 112 dias. Os remanescentes foram distribuídos aleatoriamente em cinco tratamentos: $0,17,34,51$ e $68 \%$ de concentrado na ração, em delineamento inteiramente casualizado. Os bovinos que não receberam concentrado tiveram seu consumo restrito para $1,5 \%$ do seu peso corporal, compondo o grupo de animais alimentados ao nível de mantença. A composição corporal e o peso de corpo vazio (PCVZ) foram obtidos pela técnica do abate comparativo e dissecação completa da meia carcaça. Para bovinos mestiços leiteiros, não castrados, confinados, as exigências líquida e metabolizável de energia para mantença foram de 86,49 e $138 \mathrm{kcal} \mathrm{PCVZ}^{-0,75}$ dia- $^{-}$ 1, respectivamente, enquanto que as eficiências de utilização da energia metabolizável (EUEM) para mantença e ganho foram de 62,67 e 31,67\%, respectivamente. Já as exigências líquidas de energia (ELg) e proteina (PLg) para ganho, podem ser estimadas a partir das seguintes equações: ELg = $0,0392 * \mathrm{PCVZ}^{0,75 *} \mathrm{GPCVZ}^{1,0529} \mathrm{e} \mathrm{PLg}=242,34 \times \mathrm{GPCVZ}-23,09 \times \mathrm{ER}$, respectivamente. A eficiência do uso da proteína metabolizável para ganho foi de $25,8 \%$ enquanto que as exigências de proteína para mantença foram 2,96 $\mathrm{g} \mathrm{PCVZ}^{-0,75} \mathrm{dia}^{-1}$. A proteína degradável no rúmen pode suprir $62,44 \%$ das exigências em proteína bruta de bovinos mestiços leiteiros, machos não castrados, em confinamento, com peso corporal de $450 \mathrm{~kg}$ e ganho de $1 \mathrm{~kg} \mathrm{dia}^{-1}$.

Palavras-chave: Composição corporal. Ganho de peso. Mantença.

\section{Introduction}

Most of the beef cattle population in Brazil comprises Zebu breeds, which is why most studies evaluate the nutritional requirements of this species (ALMEIDA et al., 2009; BACKES et al., 2005, 2010; COSTA E SILVA et al., 2012; FREITAS et al., 2006; MARCONDES et al., 2011a, 2011b; SOUZA et al., 2012a, 2012b). However, male cattle raised in dairy farms are also used for meat production; however, their performance is poorer compared with that of Zebu, and thus, many producers prefer to slaughter them as calves.

Several studies conducted with Holstein $\mathrm{x}$ Zebu crossbreds showed that this type of cattle has the potential for meat production (ALVES et al., 2004; COSTA et al., 2007). Nevertheless, adequate management is required to improve the zootechnical indices to ensure market survival and increase the offtake rate, which may be achieved by means of confinement.

Analysis of animal body composition allows evaluating the nutritional value of feeds, animal growth and estimated energy and protein requirements for weight gain and maintenance and consequently, allows the amount of feed to be adjusted at minimal cost and improve production efficiency.

A table with the nutritional needs of Zebu purebreds and crossbreds - BR CORTE - was published in Brazil in 2010 (VALADARES FILHO et al., 2010). However, this database only includes one study with Holstein x Zebu crossbreds (BACKES et al., 2005), which was performed in southeast Brazil. Few studies have assessed the nutritional requirements of beef cattle in the northeast region of the country (ANDRADE et al., 2008, 2009; NASCIMENTO et al., 2009); two such studies were conducted with pastureraised crossbred dairy cattle, and a third study was conducted with Holstein calves.

Because of the wide variation in conditions (animal species, breed and age, food availability and quality and peculiarities inherent to the various geographic regions and seasons) in Brazil compared with other countries and also within the 
country, a study of the nutritional requirements of cattle under different raising conditions is necessary.

Therefore, the objective of this study is to predict the energy and protein requirements of crossbred dairy bulls raised in confinement in the Pernambuco semiarid.

\section{Materials and Methods}

The experiment was conducted at the Unidade Acadêmica de Serra Talhada, Universidade Federal Rural de Pernambuco, Pernambuco (PE), Brazil with approval of the Animal Use Ethics Committee, ruling no. 23082.015634/2012-41. A total of 30 dairy crossbred bulls with a mean body weight $(\mathrm{BW})$ of $339.1 \pm 35.4 \mathrm{~kg}$ were used. At the beginning of the experiment, the animals were weighed, identified, treated against ecto- and endoparasites and given injectable vitamin A, D and $E$ supplements. Next, they were confined in flat wire-fenced individual stalls with areas of 27 $\mathrm{m}^{2}$, of which, $6 \mathrm{~m}^{2}$ had fiber cement roofing and a 1-m feeder; drinkers were shared between two stalls.

Following a 40-day adaptation period during which all the animals were given the same feed (80:20 roughage:concentrate ratio), five animals were randomly selected for the reference group, which were slaughtered at the beginning of the experiment to estimate the body composition and empty body weight (EBW) of the remainder of the animals at baseline. The other 25 animals were randomly allocated to the treatment groups, which were given feeds containing $0,17,34,51$ or $66 \%$ of concentrate on a dry matter basis for 112 days. Tifton hay (Cynodon dactylon (L.) Pers.) was used as roughage, and water was available ad libitum throughout the experiment. The proportion of the concentrate ingredients and chemical composition of concentrate and experimental feeds are described in Tables 1 and 2 .
Table 1. Percentage composition of concentrates and chemical composition of the concentrates and hay.

\begin{tabular}{|c|c|c|}
\hline Concentrate ingredients & & $\%$ \\
\hline Ground corn & & 67.10 \\
\hline Soybean meal & & 15.00 \\
\hline Wheat meal & & 12.27 \\
\hline Livestock urea & & 1.26 \\
\hline Ammonium sulphate & & 0.14 \\
\hline Sodium chloride & & 1.00 \\
\hline Mineral mixture $^{1}$ & & 1.00 \\
\hline Calcitic limestone & & 0.73 \\
\hline Sodium bicarbonate & & 1.00 \\
\hline Magnesium oxide & & 0.50 \\
\hline Nutritional components & Concentrate & Hay \\
\hline Dry Matter ${ }^{2}$ & 895.93 & 890.40 \\
\hline Organic Matter ${ }^{3}$ & 913.02 & 932.17 \\
\hline Crude Protein ${ }^{3}$ & 192.84 & 92.60 \\
\hline Neutral Detergent Fibre ${ }^{3}$ & 167.16 & 708.05 \\
\hline Acid Detergent Fibre ${ }^{3}$ & 55.90 & 284.80 \\
\hline Total Carbohydrates ${ }^{3}$ & 732.55 & 823.58 \\
\hline Non -Fibre Carbohydrates ${ }^{3}$ & 565.39 & 115.53 \\
\hline Ether Extract ${ }^{3}$ & 33.72 & 23.42 \\
\hline
\end{tabular}

${ }^{1}$ Mineral mixture composition: Ca 132,72 ( $\left.\mathrm{g} \mathrm{kg}^{-1}\right)$; P 96,86; (g $\left.\mathrm{kg}^{-1}\right)$; S 38,00 ( $\left.\mathrm{g} \mathrm{kg}^{-1}\right)$; Co 66,42 (mg kg-1); Cu 1.810,44 (mg kg$\left.{ }^{1}\right)$; Fe 2.846,46 (mg kg-1); I 89,55 (mg kg-1); Mn 1.774,63 (mg $\left.\mathrm{kg}^{-1}\right)$; Se 14,92 (mg kg $\left.{ }^{-1}\right)$; Zn 4.298,51 (mg kg-1 $)$; F 968,60 (mg $\left.\mathrm{kg}^{-1}\right){ }^{2} \mathrm{~g} \mathrm{~kg}^{-1}$ of natural matter; ${ }^{3} \mathrm{~g} \mathrm{~kg}^{-1}$ of dry matter.

The animals were fed twice a day at 9:00 am and 4:00 pm. The feed amount was adjusted every two days, which allowed for $5.2 \%$ of leftovers to ensure ad libitum intake, except for the animals in the maintenance group ( $0 \%$ of concentrate); the feed amount corresponded to $1.5 \% \mathrm{BW}$. The feed and leftover amounts were recorded daily to estimate the dry matter intake (DMI). Concentrate, hay and leftover samples were collected weekly from each individual stall. Those samples were partially dried and proportionally pooled per the 28-day period and were later used as compound samples for laboratory testing.

Partial drying was performed using the INCTCA G-001/1 method. Compound samples of concentrate, hay, leftovers and feces from each 
animal were ground in a mill with 1-mm mesh sieve to be later used in the following laboratory measurements: dry mass (DM) following the INCT-CA G-003/1 method; mineral matter (MM) according to the INCT-CA M-001/1 method; ether extract (EE) following the INCT-CA G-004/1 method; neutral detergent fiber (NDF) by means of the INCT-CA F-002/1 method; acid detergent fiber (ADF) by means of the INCT-CA F-004/1 method; nitrogen $(\mathrm{N})$ by means of the INCT-CA N-001/1 method, and the crude protein (CP) content was calculated by multiplying $\mathrm{N}$ times 6.25 , as described by Detmann et al. (2012).

Table 2. Chemical composition of experimental diets.

\begin{tabular}{lccccc}
\hline \multirow{2}{*}{ Nutritional components } & \multicolumn{5}{c}{ Concentrate levels (\% DM) } \\
\cline { 2 - 5 } & 0 & 17 & 34 & 51 & 68 \\
\hline Dry Matter $^{1}$ & 890.40 & 891.34 & 892.28 & 893.22 & 894.16 \\
Organic Matter $^{2}$ & 932.17 & 928.91 & 925.66 & 922.40 & 919.15 \\
Crude Protein $^{2}$ & 92.60 & 109.64 & 126.68 & 143.72 & 160.76 \\
Neutral Detergent Fibre $^{2}$ & 708.05 & 616.10 & 524.15 & 432.20 & 340.25 \\
Acid Detergent Fibre $^{2}$ & 284.80 & 245.89 & 206.97 & 168.06 & 129.15 \\
Total Carbohydrates $^{2}$ & 823.58 & 808.11 & 792.63 & 777.15 & 761.68 \\
Non-Fibre Carbohydrates $^{2}$ & 115.53 & 192.00 & 268.48 & 344.96 & 421.43 \\
Ether Extract $^{2}$ & 23.42 & 25.17 & 26.92 & 28.67 & 30.42 \\
Total Digestible Nutrients $^{2, *}$ & 563.46 & 574.41 & 635.24 & 678.69 & 732.37 \\
Metabolizable Energy $^{3, * *}$ & 203.71 & 207.67 & 229.66 & 245.37 & 264.78 \\
\hline
\end{tabular}

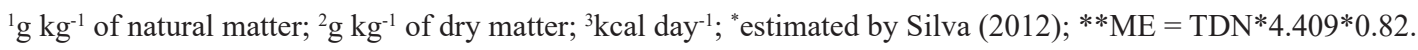

The non-fiber carbohydrates (NFC), total carbohydrates (TC), total digestible nutrients (TDN) intake and content and metabolizable energy (ME) of the feeds were calculated using the following equations: $\mathrm{NFC}=100-[(\% \mathrm{CP}-\% \mathrm{CP}$ urea $+\%$ urea $)$ $+\% \mathrm{NDF}+\% \mathrm{EE}+\% \mathrm{MM}]$ following Hall (2000); $\mathrm{TC}=100-(\% \mathrm{CP}+\% \mathrm{EE}+\% \mathrm{MM})$ and $\mathrm{TDNI}=(\mathrm{CPI}$ $\left.-\mathrm{CP}_{\mathrm{f}}\right)+2.25^{*}\left(\mathrm{EEI}-\mathrm{EE}_{\mathrm{f}}\right)+\left(\mathrm{TCI}-\mathrm{TC}_{\mathrm{f}}\right)$ following Sniffen et al. (1992), where TDNI, CPI, EEI and TCI represent the NDT, CP, EE and TC intake, respectively; $\mathrm{CP}_{\mathrm{f}}, \mathrm{EE}_{\mathrm{f}}$ and $\mathrm{TC}_{\mathrm{f}}$ represent the $\mathrm{CP}, \mathrm{EE}$ and $\mathrm{TC}$ fecal excretion, respectively; and $\% \mathrm{TDN}=$ (TDNI/DMI)*100. The organic matter (OM) content was also calculated as follows: $\% \mathrm{OM}=100$ - \%MM.

Tests were performed to determine the apparent DM, OM, CP, EE, NDF and ADF digestibilities. Feces were collected directly from the animals' rectal ampulla before feeding on experimental days 98 to 108 . Feed and waste samples were also collected concurrently. The feces, feed and leftover samples were partially dried and proportionally pooled to create compound samples that were later used in laboratory testing.

The fecal dry mass production was estimated using the indigestible acid detergent fiber $\left(\mathrm{ADF}_{\mathrm{i}}\right)$ as the indicator. Feces, hay, concentrate and leftover samples were partially dried, ground in a mill with 2-mm mesh sieve and incubated in the rumen of a fistulated animal for 264 hours (CASALI et al., 2008). The resulting material was subjected to acid detergent extraction, the residue of which was considered the $\mathrm{ADF}_{\mathrm{i}}$.

The intake of ME was calculated based on the NRC (2000) protocol, according to which, $1 \mathrm{~kg}$ of TDN corresponds to 4.409 Mcal of digestible 
energy (DE) and $1 \mathrm{Mcal}$ of ME to $0.82 \mathrm{Mcal}$ of DE. The ME concentration in the feeds was calculated based on the ratio of ME intake to DM intake. The animals' nutritional requirements were predicted using the comparative slaughter method following Lofgreen and Garrett (1968).

The total duration of the experiment was 112 days, which was divided into four 28-day periods. The animals were weighed at the end of each period after a 16-hour fast. The animals were slaughtered at the end of the experiment. Slaughter was performed every other day for a total of five days; one animal from each treatment group was slaughtered per session. This procedure was performed at the municipal slaughterhouse of Serra Talhada, PE.

Before slaughter, the animals were weighed after a 16-hour solid food fast. The slaughter procedure followed Normative Ruling no. 3, from 17 January 2000 (BRASIL, 2000). Stunning was performed by means of the mechanical percussive method with penetration using a pneumatic captive bolt pistol. Stunning was immediately followed by bleeding by severing the jugular vein and carotid artery. The blood was collected, weighed and sampled. It was then placed in a previously weighed glass container and dried in a forced air oven at 55-60 ${ }^{\circ} \mathrm{C}$ for $48-72$ hours. Then, the blood was ground in a ball mill and remained frozen until being used for DM, CP and EE measurements.

Bleeding was followed by flaying and evisceration. Next, the head (severed at the level of the atlanto-occipital joint), limbs (severed at the level of the carpal and tarsometatarsal joints), tail and testicles were removed to determine the hot carcass weight. The gastrointestinal tract (rumen/ reticulum, omasum, abomasum, small and large intestines) was weighed empty. The internal fat and each organ were weighed separately. The internal fat comprised the fat removed from the organs and viscera, omentum and mesentery. The EBW was calculated by summing the weight of the empty body components, namely, the organs, viscera, internal fat, leather, head, feet, tail, carcass and blood.

The ratio of EBW to $\mathrm{BW}$ of the reference animals was used to estimate the EBW at baseline and the empty body weight gain (EBWG) of the animals that remained in the experiment. One animal from each treatment group was randomly selected to collect head, front and hind limb samples for physical separation of the muscles, fat, bones and leather.

All of the carcasses were halved, weighed and cooled in cold chamber at $4{ }^{\circ} \mathrm{C}$ for approximately 24 hours. Next, the half-carcasses were removed from the cold chamber and weighed. In the right half-carcasses, the bone was separated from the other tissues; the muscle and adipose tissue were ground in a meat grinder, and the bones were separated (long bones, vertebrae and ribs), sawed and proportionally divided into 300 -g samples.

The rumen, reticulum, omasum, abomasum, small and large intestines and internal fat were ground in a cutter to collect the composite viscera sample. The liver, heart, kidneys, lungs, tongue, spleen, diaphragm and trimmings (esophagus, trachea and reproductive system) were ground in a cutter to collect the composite organs sample. A $400-\mathrm{cm}^{2}$ sample was taken from the posterior left area of the leather of each animal and chopped. The tails were sawed into small pieces.

In addition to the blood samples, the ground organ (200 g), viscera (200 g) and fat-containing muscle $(200 \mathrm{~g})$ and the chopped leather $(100 \mathrm{~g})$, bone $(100 \mathrm{~g})$ and tail $(100 \mathrm{~g})$ samples were placed in $500-\mathrm{mL}$ flasks and dried in an oven at $105{ }^{\circ} \mathrm{C}$ for 48 to 72 hours. Those samples were used to determine the fatty dry matter (FDM) and were then defatted by means of successive washings with petroleum ether to determine the defatted dry matter (DDM). Next, the samples were ground in a ball mill for DM, N and CP measurements, as described above and EE by means of the INCT-CA G-005/1 method, though with an extraction time of 
four hours (DETMANN et al., 2012). The amount of fat removed during defatting was calculated as the difference between FDM and DDM and added to the results corresponding to the residual EE in DDM to calculate the total fat content. The measured $\mathrm{N}$ and EE content in DDM and the weight of the samples subjected to defatting were used to determine the corresponding parameters in the fresh matter.

The body fat, protein and water content were determined based on their percent concentration in the organs, viscera, skin, blood, tail, feet (fat and bones) and individual carcass components (muscle + fat and bones).

The energy concentration was calculated based on the body protein and fat content and respective caloric equivalents and using the equation recommended by $\mathrm{ARC}$ (1980): $\mathrm{EC}=5.6405 \mathrm{X}+$ 9.3929 $\mathrm{Y}$, where $\mathrm{EC}=$ energy content (Mcal), $\mathrm{X}=$ protein content $(\mathrm{kg})$ and $\mathrm{Y}=$ fat content $(\mathrm{kg})$.

To convert BW into EBW and body weight gain $(\mathrm{BWG})$ into EBWG, the ratio of EBW $(\mathrm{kg})$ to BW $(\mathrm{kg})$ and of BWG $\left(\mathrm{kg} \mathrm{day}^{-1}\right)$ to EBWG $\left(\mathrm{kg} \mathrm{day}^{-1}\right)$ of the animals that remained in the experiment were calculated. Those ratios were used to convert the EBWG requirements into BWG requirements.

To calculate the net energy for gain $\left(\mathrm{NE}_{\mathrm{g}}\right)$, a regression equation relating retained energy (RE, Mcal day $\left.{ }^{-1}\right)$ to metabolic EBW $\left(\mathrm{EBW}^{0.75}\right)$ and EBWG $\left(\mathrm{kg} \mathrm{day}^{-1}\right)$ of the animals during the growing phase was used: $\mathrm{RE}=\beta_{0}{ }^{*} \mathrm{EBW}^{0.75 * E B W G}{ }^{\beta 1}$.

The efficiency of use of ME for weight gain $\left(k_{g}\right)$ was determined as the regression coefficient $\left(\beta_{1}\right)$ between RE (Mcal EBW ${ }^{-0.75}$ ) and metabolic energy intake (MEI) (Mcal EBW ${ }^{-0.75}$ ) of the animals that remained in the experiment according to the equation: $\mathrm{RE}=\beta_{0}+\beta_{1}{ }^{*} \mathrm{MEI}$, where $\beta_{0}$ and $\beta_{1}$ are the equation parameters.

The orthogonal regression method was used to obtain parameters $\beta_{0}$ and $\beta_{1}$ following Fuller (1987) because it was assumed that there are errors associated with both variables (RE and MEI). The equation parameters were obtained as follows: $\beta_{0}=\mathrm{Y}-\beta_{1} \mathrm{X}$ and $\beta_{1}=\left(\sigma_{\mathrm{y}}^{2}-\sigma_{\mathrm{x}}^{2}+\left(\left(\sigma_{\mathrm{y}}^{2}-\sigma_{\mathrm{x}}^{2}\right)^{2}+\right.\right.$ $\left.\left.\left.4 \sigma_{x y}{ }^{2}\right)^{0.5}\right)\right) / 2 \sigma_{x y}$, where $X=$ mean MEI, $Y=$ mean RE, $\sigma^{2}{ }_{x}=$ variance of $X, \sigma_{y}^{2}=$ variance of $Y$ and $\sigma_{x y}=$ covariance between $\mathrm{X}$ and $\mathrm{Y}$.

The fasting heat production was determined in the animals that remained in the experiment. The fasting heat production represents the net energy required for maintenance $\left(\mathrm{NE}_{\mathrm{m}}\right)$, which is equivalent to the intercept $\left(\beta_{0}\right)$ of the exponential regression equation between the heat production (HP, Mcal EBW-0.75) and EMI (Mcal EBW-0.75) according to Ferrell and Jenkins (1998): $\mathrm{Y}=$ $\beta_{0}{ }^{*} \mathrm{e}^{\beta 1 * \mathrm{X}}$, where $\mathrm{Y}=\mathrm{HP}\left(\mathrm{kcal} \mathrm{EBW}^{-0.75}\right) ; \beta_{0}$ is the intercept $\left(\mathrm{NE}_{\mathrm{m}}\right)$; “e”= Euler's number (2.7183); and $\mathrm{X}=\mathrm{MEI}\left(\mathrm{kcal} \mathrm{EBW}^{-0.75}\right)$. The iterative method was used to establish the point where MEI and HP became equal; the corresponding value was considered as the $\mathrm{NE}_{\mathrm{m}}$ requirements. The efficiency of use of metabolizable energy for maintenance $\left(k_{m}\right)$ was estimated based on the relationship between the net and metabolizable energy requirements for maintenance obtained by means of this model.

The net protein required for gain $\left(\mathrm{NP}_{\mathrm{g}}\right)$ was estimated based on a model that considers the EBWG and RE of animals during the growing phase as parameters: $\mathrm{NP}_{\mathrm{g}}=\beta_{0}{ }^{*} \mathrm{EBWG}+\beta_{1}{ }^{*} \mathrm{RE}$, where $\mathrm{NP}_{\mathrm{g}}=$ net protein for gain requirements ( $\mathrm{g}$ day $\left.^{-1}\right) ; \mathrm{EBWG}=$ empty body weight gain $\left(\mathrm{kg}\right.$ day $^{-}$ $\left.{ }^{1}\right) ; \mathrm{RE}=$ retained energy $\left(\mathrm{Mcal}_{\mathrm{day}}{ }^{-1}\right) ; \beta_{0}$ and $\beta_{1}=$ regression parameters.

The model suggested by Valadares Filho et al. (2010) was used to calculate the metabolizable protein requirements for maintenance $\left(\mathrm{MP}_{\mathrm{m}}\right)$, in which the metabolizable protein intake (MPI) was contrasted with the EBWG of the animals during growth and maintenance: $\mathrm{MPI}=\beta_{0}+\beta_{1}$ *EBWG, where MPI = metabolizable protein intake $\left(\mathrm{g}\right.$ day $\left.^{-1}\right)$; EBWG = empty body weight gain $\left(\mathrm{kg} \mathrm{day}^{-1}\right) ; \beta_{0}$ and $\beta_{1}=$ regression parameters. 
The relationship between the intercept of this regression by $\mathrm{EBWG}^{0.75}$ allowed estimating the $\mathrm{MP}_{\mathrm{m}}$ requirements $\left(\mathrm{MP}_{\mathrm{m}}=\beta_{0} / \mathrm{EBW}^{0.75}, \mathrm{~g} \mathrm{EBW}^{-0.75}\right.$ day $\left.^{-1}\right)$.

Alternatively and using the same group of animals, the retained protein (RP) was plotted against MPI: $\mathrm{RP}=\beta_{0}+\beta_{1} * \mathrm{MPI}$, where $\mathrm{RP}=$ retained protein $\left(\mathrm{g} \mathrm{EBW}^{-0.75}\right.$ day $\left.^{-1}\right)$; $\mathrm{MPI}=$ metabolizable protein intake $\left(\mathrm{g} \mathrm{EBW}{ }^{-0.75} \mathrm{day}^{-1}\right) ; \beta_{0}$ and $\beta_{1}=$ regression parameters, where $\beta_{1}=$ efficiency of use of metabolizable protein for gain. The coefficients $\beta_{0}$ and $\beta_{1}$ in the two last models described were also estimated by means of Fuller's (1987) orthogonal regression method.

The rumen degradable (RDP) and undegradable (RUP) protein requirements were estimated based on the efficiency of synthesis of microbial protein from $120 \mathrm{~g}$ of microbial crude protein (MCP) per $\mathrm{kg}$ of TDNI with an assumed efficiency of conversion of rumen-degraded nitrogen into microbial nitrogen of $90 \%$. Therefore, the RDP requirements were calculated as $1.11 * \mathrm{MCP}$ following Valadares Filho et al. (2010). The RUP was calculated using the following equation: RUP $=[(\mathrm{MP}-$ $(\mathrm{MCP} * 0.64)] / 0.80$, where $\mathrm{MP}=$ total metabolizable protein requirements (VALADARES FILHO et al., 2010). The CP was calculated by summing RDP and RUP. The CP requirements, expressed as $\% \mathrm{DM}$, were estimated based on the DMI adjusted to the PC and daily BWG $\left(\mathrm{kg} \mathrm{day}^{-1}\right)$ of the animals during the growing phase according to a model similar to the one used by Valadares Filho et al. (2010).

The experiment followed a completely randomized design with five treatments (concentrate levels) and five replicates (animals). The aforementioned equations were constructed using the nonlinear models method (SAS procedure NLIN) using the Gauss-Newton iterative algorithm.

\section{Results and Discussion}

The BW and EBW of the experimental animals did not differ among the treatment groups at baseline. However, the increase in the concentrate percentage in the feeds was associated with higher BW and EBW at the end of the experiment, exhibiting a linear increase. This pattern reflected the increase in TDN and ME intake resulting from the increase in the concentrate percentage in the feeds, which had the same effect on the average daily gain (ADG) and EBWG. The BW and EBW of the animals that were not given concentrate (maintenance group) were lower compared with those of all the others. It is important to note that these findings are consistent with the objective of the present study, which was to maintain the BW of the animals in the maintenance group, where the ADG and EBWG were $-0.02 \mathrm{~kg}$ and $0.01 \mathrm{~kg}$, respectively (Table 3 ).

The equation obtained for the EBW based on $\mathrm{BW}$ was $\mathrm{EBW}=0.85 * \mathrm{BW}$. While this value is within the range of variation ( 85 to $95 \%$ ) suggested by NRC (2000), it is lower than the values established by the aforementioned committee (0.891) and Valadares Filho et al. (2010) for animals in confinement $(0.895)$ as well as the values determined by Prados (2012), i.e., 0.9034, and Rotta et al. (2013), i.e., 0.8834, for Holstein $\mathrm{x}$ Zebu crossbreds in confinement. However, the value of 0.85 is close to the values estimated by Backes et al. (2005), Zervoudakis et al. (2002) and Nascimento et al. (2009), who determined values of $0.865,0.8575$ and 0.8581 , respectively; the former two studies were conducted with Holstein $\mathrm{x}$ Zebu crossbreds and the latter with Holstein calves. 
Table 3. Body weight (BW) and empty body weight (EBW), average daily gain (ADG), empty body weight gain (EBWG), total digestible nutrients intake (TDNI) and metabolizable energy intake (MEI) of crossbred dairy bulls fed with different concentrate proportions

\begin{tabular}{|c|c|c|c|c|c|c|c|c|}
\hline \multirow{2}{*}{ Item } & \multicolumn{5}{|c|}{ Concentrate levels (CL, \% DM) } & \multirow{2}{*}{$\hat{\mathrm{Y}}$} & \multirow{2}{*}{$\mathrm{R}^{2}(\%)$} & \multirow{2}{*}{$\begin{array}{l}\text { CV } \\
(\%)\end{array}$} \\
\hline & 0 & 17 & 34 & 51 & 68 & & & \\
\hline $\mathrm{BW}_{\text {initial }} 1$ & $343.40 \mathrm{a}$ & $343.60 \mathrm{a}$ & $343.80 \mathrm{a}$ & $343.40 \mathrm{a}$ & $343.40 \mathrm{a}$ & $\hat{\mathrm{Y}}=343.52$ & & 11.11 \\
\hline $\mathrm{BW}_{\text {final }}{ }^{1}$ & $341.60 \mathrm{~b}$ & $449.00 \mathrm{a}$ & $459.00 \mathrm{a}$ & $488.80 \mathrm{a}$ & $504.40 \mathrm{a}$ & $\mathrm{BW}_{\mathrm{f}}=338.94+36.54 * \mathrm{CL}$ & 83.66 & 11.96 \\
\hline $\mathrm{EBW}_{\text {initial }}{ }^{1}$ & $277.03 \mathrm{a}$ & 277.19a & $277.35 \mathrm{a}$ & $277.03 \mathrm{a}$ & $277.03 \mathrm{a}$ & $\hat{\mathrm{Y}}=277.12$ & & 11.11 \\
\hline $\mathrm{EBW}_{\text {final }} 1$ & $278.21 \mathrm{~b}$ & $376.32 \mathrm{a}$ & $392.39 \mathrm{a}$ & $426.22 \mathrm{a}$ & $446.59 \mathrm{a}$ & $\mathrm{EBW}_{\mathrm{f}}=267.95+38.67 * \mathrm{CL}$ & 89.12 & 12.16 \\
\hline $\mathrm{ADG}^{2}$ & $-0.02 \mathrm{c}$ & $0.90 \mathrm{~b}$ & $0.97 \mathrm{~b}$ & $1.24 \mathrm{ab}$ & $1.36 \mathrm{a}$ & $\mathrm{ADG}=0.042+0.31 * \mathrm{CL}$ & 83.94 & 22.49 \\
\hline $\mathrm{EBWG}^{2}$ & $0.01 d$ & $0.84 d$ & $0.97 \mathrm{bd}$ & $1.27 \mathrm{ab}$ & $1.43 \mathrm{a}$ & $\mathrm{EBWG}=0.08+0.33 * \mathrm{CL}$ & 89.42 & 21.47 \\
\hline $\mathrm{TDNI}^{2}$ & $2.76 \mathrm{c}$ & $4.84 b$ & $6.03 \mathrm{ab}$ & $6.91 \mathrm{a}$ & $7.65 \mathrm{a}$ & $\mathrm{TDNI}=2.08+1.18 * \mathrm{CL}$ & 95.25 & 17.56 \\
\hline $\mathrm{MEI}^{3}$ & $9.98 \mathrm{c}$ & $17.50 \mathrm{~b}$ & 21.81ab & $25.00 \mathrm{a}$ & $27.64 \mathrm{a}$ & $\mathrm{MEI}=7.54+4.28 * \mathrm{CL}$ & 95.25 & 17.56 \\
\hline
\end{tabular}

Means followed by differents letters in the line differ significantly by Tukey test at $5 \%,{ }^{1} \mathrm{~g} \mathrm{~kg}^{-1} ;{ }^{2} \mathrm{~kg} \mathrm{day}^{-1} ;{ }^{3} \mathrm{Mcal} \mathrm{day}^{-1}$.

The differences mentioned above may have been due to the degree of Holstein blood in the experimental animals because the gastrointestinal tract is larger in dairy cattle than in beef cattle. Similar results were reported by Silva et al. (2002), who found that the EBW/BW ratio was higher in Zebu and European $x$ Zebu crossbreds (0.88) compared with that of Holstein and their crossbreeds (0.83). As it is known, feeds with a higher fiber content allow for longer food retention time in the gastrointestinal tract, which is a factor that may also account for the differences in the experimental results.

The relationship between BWG and EBWG, which is required to convert EBWG requirements into BWG requirements was EBWG $\left(\mathrm{kg} \mathrm{day}^{-1}\right)=$ $0.95 * \mathrm{BWG}\left(\mathrm{kg} \mathrm{day}^{-1}\right)$. In other words, under the present study conditions, the net requirements for daily gain of $1 \mathrm{~kg}$ of $\mathrm{BW}$ were equivalent to the requirements for daily gain of $0.95 \mathrm{~kg}$ of EBW. The factor of 0.95 is close to the one recommended by NRC (2000) for cattle in general and by Backes et al. (2005) for crossbred Holstein x Zebu cattle (factor of 0.96) as well as the factor found by Silva et al. (2002) and Prados (2012) for crossbred dairy cattle (factor of 0.94); the value estimated by Valadares Filho et al. (2010) for Zebu and crossbred cattle in confinement was 0.966 .
The following equation was obtained for the exponential relationship between HP (kcal EBW-0.75 day $^{-1}$ ) and MEI (kcal EBW ${ }^{-0.75}$ day $\left.^{-1}\right): H P=86.486$ $\mathrm{e}^{0.0034^{*} \mathrm{MEI}}$. The intercept of this equation represents the net daily energy requirement for maintenance $\left(\mathrm{NE}_{\mathrm{m}}\right)$, which was $86.49 \mathrm{kcal}_{\mathrm{EBW}}{ }^{-0.75}$ day $^{-1}$. The $\mathrm{NE}_{\mathrm{m}}$ adopted by NRC (2000) is $77 \mathrm{kcal} \mathrm{EBW}^{-0.75}$ day $^{-1}$, as recommended by Lofgreen and Garrett (1968) for steers and heifers with a $15 \%$ addition for bulls for a total $\mathrm{NE}_{\mathrm{m}}$ of $88.55 \mathrm{kcal} \mathrm{EBW}^{-0.75}$ day $^{-1}$ and thus, is close to the one estimated in the present study. However, the $\mathrm{NE}_{\mathrm{m}}$ of $86.49 \mathrm{kcal} \mathrm{EBW}^{-0.75} \mathrm{day}^{-}$ ${ }^{1}$ is higher than that found by Porto et al. (2012), which was $71.9 \mathrm{kcal} \mathrm{EBW}^{-0.75}$ day $^{-1}$ for pastureraised Nelore $\mathrm{x}$ Holstein crossbreds, and by Prados (2012) and Rotta et al. (2013), which were 68.9 and $78.7 \mathrm{kcal} \mathrm{EBW}^{-0.75}$ day $^{-1}$, respectively, for Holstein $\mathrm{x}$ Zebu crossbreds in confinement.

However, because crossbred dairy cattle have a greater capacity to accumulate internal fat compared with beef cattle (BACKES et al., 2010; FERNANDES et al., 2005) and because internal fat is metabolically more active than external fat, the energy expenditure for its deposition and maintenance is higher and directly influences the energy requirements for maintenance (VALADARES FILHO et al., 2006). Thus, the increase in internal fat deposition associated with 
increased concentrate in the cattle found by Neves (2013) with the same animals of this study may have contributed to the high $\mathrm{NE}_{\mathrm{m}}$ found compared with the data reported in the Brazilian literature. Silva et al. (2002) also observed a higher $\mathrm{NE}_{\mathrm{m}}$ requirement in Holstein (88.97 $\mathrm{kcal} \mathrm{EBW}^{-0.75}$ day $^{-}$ $\left.{ }^{1}\right)$ and crossbred dairy (79.65 $\mathrm{kcal} \mathrm{EBW}^{-0.75}$ day $\left.^{-1}\right)$ cattle compared with Zebu (71.3 $\mathrm{kcal} \mathrm{EBW}^{-0.75}$ day $^{-}$ $\left.{ }^{1}\right)$ and its crossbreeds $\left(70.77 \mathrm{kcal} \mathrm{EBW}^{-0.75}\right.$ day $\left.^{-1}\right)$.

Based on the exponential equation relating HP and MEI and by means of an iterative process, metabolizable energy for maintenance $\left(\mathrm{ME}_{\mathrm{m}}\right)$ was estimated as $138 \mathrm{kcal} \mathrm{EBW}^{-0.75}$ day $^{-1}$, which represents the point at which HP became equal to MEI. This value is higher than the one estimated by Valadares Filho et al. (2006) and Costa e Silva et al. (2012) for Nellore bulls (120.0 and 113.84 $\mathrm{kcal} \mathrm{EBW}^{-0.75}$ day $^{-1}$, respectively), by Marcondes et al. (2011a) for Nellore and crossbred steers (112.82 kcal EBW ${ }^{-0.75}$ day $^{-1}$ ) and by Prados (2012) and Rotta et al. (2013) for Holstein x Zebu crossbreds in confinement (90.17 and $114.2 \mathrm{kcal} \mathrm{EBW}^{-0.75}$ day $^{-}$ ${ }^{1}$, respectively). These differences were expected because energy requirements may vary among genetic groups (SIQUEIRA et al., 2007).

The $\mathrm{NE}_{\mathrm{m}} / \mathrm{ME}_{\mathrm{m}}$ ratio was used to estimate the efficiency of the use of metabolizable energy for maintenance $\left(k_{m}\right)$, which was $62.67 \%$. This value is less than the that estimated by Ferrell and Jenkins (1998) for purebred sires and their crossbred offspring (65 to $69 \%$ ); by Valadares Filho et al. (2006) for Zebu bulls (66\%); by Prados (2012) and Rotta et al. (2013) for Holstein x Zebu crossbreds in confinement (76.41\% and $68.91 \%$, respectively) and by Costa e Silva et al. (2012) and Marcondes et al. (2011a) for confined Nellore purebreds and crossbred Nellore $\mathrm{x}$ Angus and Nellore $\mathrm{x}$ Simmental bulls, respectively (67\%). However, the value found in the present study is higher than the one estimated by Porto et al. (2012), which was 58\% for pasture-raised Nellore x Holstein crossbreds. These differences are related to the higher energy concentration in the feeds given to confined animals compared with pasture-raised cattle that were not given any supplements.

The following equation was obtained to estimate $\mathrm{NE}_{\mathrm{g}}$ for any weight and weight gain

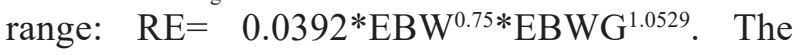
exponent of EBWG is lower compared with the equations presented by NRC (2000): RE

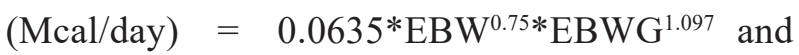
Valadares Filho et al. (2006): RE (Mcal/day)= $0.0529 * \mathrm{EBW}^{0.75 *} \mathrm{EBWG}^{1.0996}$ for bulls. This finding shows that the energy retention of the animals in the present study was lower in EBWG compared with the one found by the abovementioned works. It is worth noting that the exponent of EBWG is greater than one, which agrees with biology, i.e., the retained energy increases with the animals' growth.

Based on the equation that was obtained $(\mathrm{RE}=$ $\left.0.0392 * \mathrm{EBW}^{0.75 * E B W G}{ }^{1.0529}\right)$, it was estimated that the RE of a dairy crossbred bull with 350 $\mathrm{kg}$ of BW and $1 \mathrm{~kg}^{\mathrm{day}}{ }^{-1}$ of BWG was $2.66 \mathrm{Mcal}$ day $^{-1}$. If the same calculation is performed with the NRC (2000) and Valadares Filho et al. (2006) equations using the EBW/BW and EBWG/BWG ratios found in the present study and considering that NRC (2000) recommends reducing the RE estimate by $18 \%$ in the case of bulls, the RE values

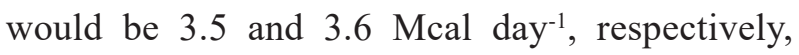
which are greater than the values estimated in the present study. These findings corroborate studies that indicated the potential of crossbred dairy cattle for meat production.

The efficiency of use of ME for weight gain $\left(k_{g}\right)$, which was $31 \%$, was estimated based on the slope coefficient $\left(\beta_{1}\right)$ of the linear regression equation relating RE and MEI (Figure 1). Porto et al. (2012), who assessed pasture-raised Nellore $\mathrm{x}$ Holstein crossbreds, and Prados (2012), who assessed $3 / 4$ Zebu and $1 / 4$ Holstein crossbreds in confinement, found a lower efficiency in use of ME for gain (24\% and $21 \%$, respectively). However, higher values 
were obtained by Costa e Silva et al. (2012) with $33 \%$; Souza et al. (2012a) with 36.41\%; Marcondes et al. (2011a) with 41\%; and Valadares Filho et al.
(2006) with $36 \%$, who assessed Nellore purebreds and its crossbreds with other breeds selected for meat production.

Figure 1. Relationship between retained energy (RE) and metabolizable energy intake (MEI).

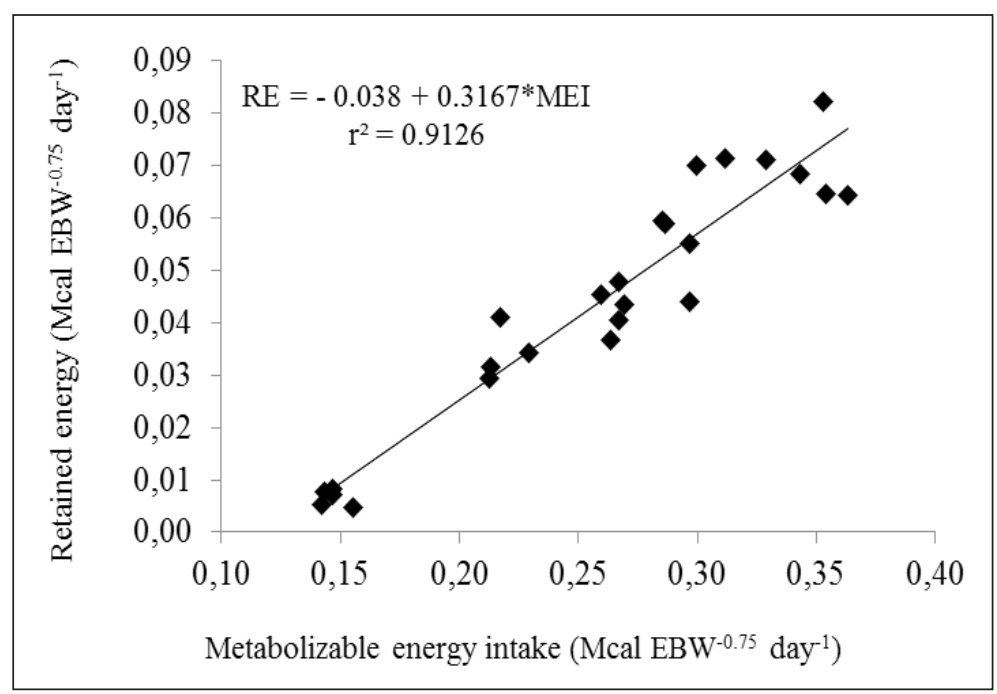

The energy requirements are described in Table 4. The results show that regardless of the way they were expressed, energy requirements increased as the BW increased. This pattern is commonly found in studies that sought to estimate the nutritional requirements of cattle, which was due to the animals' growth and characterized by the deposition of protein- and fat-rich tissues. The energy requirements estimated in the present study were higher than those found by Valadares Filho et al. (2010) for Nellore and Zebu crossbred bulls and by Costa e Silva et al. (2012) for Nellore bulls.

The value of $\mathrm{MP}_{\mathrm{m}}$, i.e., $2.96 \mathrm{~g} \mathrm{EBW}^{-0.75}$ day $^{-1}$ (228.68/77.39) or $2.63 \mathrm{~g} \mathrm{BW}^{-0.75} \mathrm{day}^{-1}$, was obtained based on the relationship between the intercept $\left(\beta_{0}\right)$ of the regression of MPI $\left(\mathrm{kg} \mathrm{day}^{-1}\right)$ as a function of the EBWG $\left(\mathrm{kg} \mathrm{day}^{-1}\right)$ of the animals in growth and maintenance $(\mathrm{MPI}=563.84 * \mathrm{EBWG}+228.68)$ per the corresponding mean $\mathrm{EBW}^{0.75}$, as suggested by NRC (2000). The value obtained is close to the one recommended by AFRC (1993) of $2.3 \mathrm{~g} \mathrm{BW}^{-}$ 0.75 day $^{-1}$ but lower than the ones established by NRC (2000) of $3.8 \mathrm{~g} \mathrm{BW}^{0.75}$ day $^{-1}$ and by Valadares Filho et al. $(2006,2010)$ of $4.0 \mathrm{~g} \mathrm{EBW}^{-0.75}$ day $^{-1}$ for Zebu cattle.

The equation to estimate $\mathrm{NP}_{\mathrm{g}}\left(\mathrm{g}_{\text {day }}{ }^{-1}\right)$ obtained based on the model that uses RP ( $\mathrm{g} \mathrm{EBW}^{-0.75}$ day $\left.^{-1}\right)$ as a function of RE (Mcal day ${ }^{-1}$ ) and EBWG (kg day $^{-1}$ ) as a parameter was $\mathrm{NP}_{\mathrm{g}}=242.34 *$ EBWG$23.09 * \mathrm{RE}$. The angular coefficient of RE is negative, which shows that RP decreases as RE increases. This pattern is due to the animal growth curve and allows inferring that the animals had already reached maturity. 
Table 4. Net energy, metabolizable energy and total digestible nutrients requirements.

\begin{tabular}{|c|c|c|c|c|c|}
\hline \multirow{2}{*}{$\begin{array}{l}\text { Weight } \\
\text { Gain }\end{array}$} & \multicolumn{4}{|c|}{ Body Weight (kg) } & \multirow[b]{2}{*}{500} \\
\hline & 300 & 350 & 400 & 450 & \\
\hline \multicolumn{6}{|c|}{ Net energy requirements (Mcal day $\left.{ }^{-1}\right)$} \\
\hline 0.00 & 5.52 & 6.20 & 6.85 & 7.48 & 8.10 \\
\hline 0.50 & 1.14 & 1.28 & 1.42 & 1.55 & 1.68 \\
\hline 1.00 & 2.37 & 2.66 & 2.94 & 3.21 & 3.48 \\
\hline 1.50 & 3.63 & 4.08 & 4.51 & 4.92 & 5.33 \\
\hline \multicolumn{6}{|c|}{ Metabolizable energy requirements $\left(\right.$ Mcal day $\left.^{-1}\right)$} \\
\hline 0.00 & 8.81 & 9.89 & 10.93 & 11.94 & 12.92 \\
\hline 0.50 & 3.61 & 4.05 & 4.48 & 4.89 & 5.29 \\
\hline 1.00 & 7.48 & 8.40 & 9.29 & 10.14 & 10.98 \\
\hline 1.50 & 11.47 & 12.87 & 14.23 & 15.54 & 16.82 \\
\hline \multicolumn{6}{|c|}{ Total metabolizable energy requirements* $\left(\mathrm{Mcal} \mathrm{day}^{-1}\right)$} \\
\hline 0.50 & 12.41 & 13.93 & 15.40 & 16.82 & 18.21 \\
\hline 1.00 & 16.29 & 18.29 & 20.21 & 22.08 & 23.89 \\
\hline 1.50 & 20.27 & 22.76 & 25.16 & 27.48 & 29.74 \\
\hline \multicolumn{6}{|c|}{ Total digestible nutrients requirements $* *\left(\mathrm{~kg} \mathrm{day}^{-1}\right)$} \\
\hline 0.00 & 2.44 & 2.73 & 3.02 & 3.30 & 3.57 \\
\hline 0.50 & 3.43 & 3.85 & 4.26 & 4.65 & 5.04 \\
\hline 1.00 & 4.51 & 5.06 & 5.59 & 6.11 & 6.61 \\
\hline 1.50 & 5.61 & 6.30 & 6.96 & 7.60 & 8.23 \\
\hline
\end{tabular}

${ }^{*}$ Total $=$ maintenance + gain $; \mathrm{EBW}=0.85 * \mathrm{BW} ; \mathrm{EBWG}=0.95 * \mathrm{BWG} ; \mathrm{NE}_{\mathrm{m}}=86.49 \mathrm{kcal} \mathrm{EBW}{ }^{-0.75} ; \mathrm{ME}_{\mathrm{m}}=138 \mathrm{kcal} \mathrm{EBW}-0.75 ; k_{m}=$ $62.67 \% ; k_{g}=31.67 \% ; \mathrm{RE}=0.0392 * \mathrm{EBW}^{0.75 *} \mathrm{EBWG}^{1.0529} ; * * \mathrm{TDN}=$ estimated according to $\mathrm{NRC}(2000): \mathrm{TDN}=(\mathrm{ME} / 0.82) / 4.409$.

Using the value of RE estimated for an animal

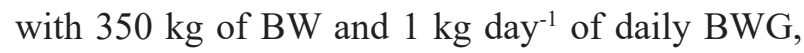
i.e., 2.66 Mcal day ${ }^{-1}$, the calculated $\mathrm{NP}_{\mathrm{g}}$ was 168.79 $\mathrm{g}$ day $^{-1}$. Using these same RE, BW and BWG values and the EBWG/BWG conversion factor of 0.95 , it can be observed that the obtained $\mathrm{NP}_{\mathrm{g}}$ value ( $\left.168.79 \mathrm{~g} \mathrm{day}^{-1}\right)$ is close to the value estimated by the equation from Valadares Filho et al. (2010), i.e., $167.93 \mathrm{~g} \mathrm{day}^{-1}$ for Nellore purebreds and crossbreds but higher compared with the ones found by Silva et al. (2002) and Porto et al. (2012), i.e., 148.30 and $147.94 \mathrm{~g} \mathrm{day}^{-1}$, respectively, for Holstein $\mathrm{x}$ Zebu bulls and lower than the one estimated by Costa e Silva et al. (2012), i.e., $187.53 \mathrm{~g} \mathrm{day}^{-1}$, for Nellore bulls. These differences are related to the body composition of the animals because Holstein $\mathrm{x}$ Zebu crossbreds during the finishing stage exhibit greater fat deposition in gain compared with beef cattle (BACKES et al., 2005). This behavior reduces the protein requirements and increases the energy requirements (FREITAS et al., 2006).

The regression between RP ( $\mathrm{gEBW}^{-0.75}$ day $^{-1}$ ) and MPI (g EBW ${ }^{-0.75}$ day $^{-1}$ ) (Figure 2) was used to calculate the efficiency of use of MP for gain, i.e., $25.8 \%$, because it corresponds to the slope coefficient $\left(ß_{1}\right)$ of that equation. The value obtained is lower than the value reported by Marcondes et al. (2011b), i.e., 37.51\%; Souza et al. (2012b), i.e., 37.04\%; AFRC (1993), i.e., 59\%; and NRC (2000), i.e., $49.2 \%$, for cattle that weigh more than $300 \mathrm{~kg}$. The efficiency of use of MP for gain is influenced by the quality of the RDP source and the biological value of the microbial protein, which depend on the amino acid composition and quality of the components of the feeds (MARCONDES et al. 2011b; SOUZA et al., 2012b). According to 
Souza et al. (2012b), the higher efficiency of use of MP for gain value suggested by NRC (2000) and AFRC (1993) is due to the quality of the food indicated by those committees in the elaboration of feeds, which are different from the ones used in the tropics in addition to the use of anabolic agents (NRC, 2000), which enhance muscle tissue growth.

Figure 2. Relationship between retained protein (RP) and metabolizable protein intake (MPI).

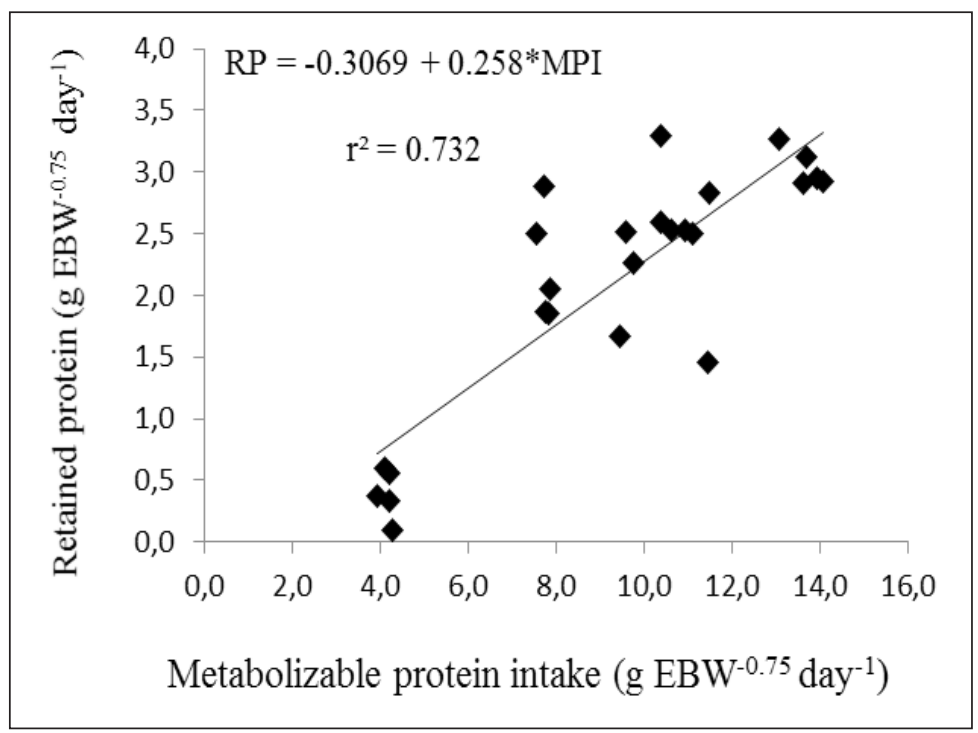

To calculate the net protein, metabolizable protein and total metabolizable protein (maintenance + gain) requirements at various weights and growth rates (Table 5), the equation to estimate the animals' RE obtained in the present study, the MP requirements for maintenance $(2.96$ g $\mathrm{EBW}^{-0.75}$ day $^{-1}$ ), efficiency of use of MP for weight gain $(25.8 \%)$ and the equation to estimate $\mathrm{NP}_{\mathrm{g}}, \quad \mathrm{NP}_{\mathrm{g}}=242.34 * \mathrm{EBWG}-23.09 * \mathrm{RE}$ were considered. Table 5 shows that as $\mathrm{MP}_{\mathrm{m}}$ increased, the BW increased, which was expected because the requirements for maintenance depend on body weight. However, while the protein requirements for gain decreased as the BW increased, the requirements increased as the desired gains increased. This pattern was also found by Souza et al. (2012b) and Costa e Silva et al. (2012) and is explained by the reduction in lean tissue deposition when the animals reach maturity. However, gain is characterized by tissue deposition and thus increases the protein requirements for gain.

The TDN (Table 4) and MP (Table 5) requirements were used to calculate the daily $\mathrm{CP}, \mathrm{RDP}$ and RUP requirements (Table 6) using the protocol formulated by Valadares Filho et al. (2010). The equation to calculate DMI as a function of $\mathrm{BW}^{0.75}$ and $\mathrm{BWG}$, which is estimated based on the data of the animals in the growing phase $\left(\mathrm{DMI}=-0.9689+0.1058 * \mathrm{BW}^{0.75}-1.2399 * \mathrm{BWG}+\right.$ $1.8329 * \mathrm{BWG}^{2}, \mathrm{R}^{2}=89.26 \%$ ), was used to predict the $\mathrm{CP}$ requirements as \%DM (Table 6). The participation of RDP in the total $\mathrm{CP}$ requirements increased as the BW increased, which thus reduced the need for dietary RUP to meet the total CP requirements. This pattern was found in various other studies (ALMEIDA et al., 2009; PORTO et al., 2012; SILVA et al. 2002; SOUZA et al., 2012b) and means that during the finishing stage, the amount of dietary non-protein nitrogen may increase as the animal weight increases (SILVA et al., 2002). 
Table 5. Net protein and metabolizable protein requirements.

\begin{tabular}{|c|c|c|c|c|c|}
\hline \multirow{2}{*}{$\begin{array}{l}\text { Weight } \\
\text { Gain }\end{array}$} & \multicolumn{5}{|c|}{ Body Weight (kg) } \\
\hline & 300 & 350 & 400 & 450 & 500 \\
\hline \multicolumn{6}{|c|}{ Net protein requirement $\left(\mathrm{g}\right.$ day $\left.^{-1}\right)$} \\
\hline 0.50 & 88.74 & 85.50 & 82.38 & 79.36 & 76.42 \\
\hline 1.00 & 175.50 & 168.79 & 162.32 & 156.05 & 149.95 \\
\hline 1.50 & 261.47 & 251.19 & 241.28 & 231.67 & 222.32 \\
\hline \multicolumn{6}{|c|}{ Metabolizable protein requirement $\left(\mathrm{g}\right.$ day $\left.^{-1}\right)$} \\
\hline 0.00 & 188.57 & 211.68 & 233.97 & 255.58 & 276.60 \\
\hline 0.50 & 343.94 & 331.41 & 319.32 & 307.60 & 296.21 \\
\hline 1.00 & 680.24 & 654.24 & 629.16 & 604.86 & 581.22 \\
\hline 1.50 & 1013.46 & 973.62 & 935.18 & 897.94 & 861.71 \\
\hline \multicolumn{6}{|c|}{ Total metabolizable protein requirement $\left(\mathrm{g} \mathrm{day}^{-1}\right)$} \\
\hline 0.50 & 532.50 & 543.08 & 553.29 & 563.19 & 572.81 \\
\hline 1.00 & 868.80 & 865.92 & 863.14 & 860.44 & 857.82 \\
\hline 1.50 & 1202.02 & 1185.30 & 1169.16 & 1153.52 & 1138.31 \\
\hline
\end{tabular}

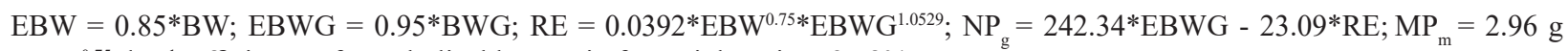
$\mathrm{EBW}^{-0.75}$ day $^{-1}$; efficiency of metabolizable protein for weight gain $=25.8 \%$.

Table 6. Total requirements (maintenance + gain) of rumen degradable protein, rumen undegradable protein and crude protein.

\begin{tabular}{|c|c|c|c|c|c|c|c|c|c|c|}
\hline \multirow{4}{*}{$\begin{array}{c}\text { BWG } \\
(\mathrm{kg})\end{array}$} & \multicolumn{10}{|c|}{ Body Weight (kg) } \\
\hline & \multicolumn{2}{|c|}{300} & \multicolumn{2}{|c|}{350} & \multicolumn{2}{|c|}{400} & \multicolumn{2}{|c|}{450} & \multicolumn{2}{|c|}{500} \\
\hline & \multicolumn{10}{|c|}{ Rumen Degradable Protein } \\
\hline & $\mathrm{g} \mathrm{day}^{-1}$ & $\% \mathrm{~PB}$ & $\mathrm{~g} \mathrm{day}^{-1}$ & $\% \mathrm{~PB}$ & $\mathrm{~g} \mathrm{day}^{-1}$ & $\% \mathrm{~PB}$ & $\mathrm{~g}_{\text {day }}{ }^{-1}$ & $\% \mathrm{~PB}$ & $\mathrm{~g} \mathrm{day}^{-1}$ & $\% \mathrm{~PB}$ \\
\hline 0.5 & 457.33 & 57.65 & 513.38 & 62.44 & 567.46 & 66.75 & 619.86 & 70.67 & 670.83 & 74.26 \\
\hline 1.0 & 600.14 & 47.87 & 673.70 & 53.02 & 744.66 & 57.87 & 813.43 & 62.44 & 880.32 & 66.79 \\
\hline \multirow[t]{3}{*}{1.5} & 746.96 & 43.65 & 838.51 & 48.87 & 926.83 & 53.88 & 1012.43 & 58.70 & 1095.68 & 63.37 \\
\hline & \multicolumn{10}{|c|}{ Rumen Undegradable Protein } \\
\hline & $\mathrm{g}_{\text {day }}{ }^{-1}$ & $\% \mathrm{~PB}$ & $\mathrm{~g} \mathrm{day}^{-1}$ & $\% \mathrm{~PB}$ & $\mathrm{~g} \mathrm{day}^{-1}$ & $\% \mathrm{~PB}$ & $\mathrm{~g} \mathrm{day}^{-1}$ & $\% \mathrm{~PB}$ & $\mathrm{~g} \mathrm{day}^{-1}$ & $\% \mathrm{~PB}$ \\
\hline 0.5 & 336.02 & 42.35 & 308.85 & 37.56 & 282.64 & 33.25 & 257.23 & 29.33 & 232.53 & 25.74 \\
\hline 1.0 & 653.47 & 52.13 & 596.85 & 46.98 & 542.23 & 42.13 & 489.29 & 37.56 & 437.81 & 33.21 \\
\hline \multirow[t]{3}{*}{1.5} & 964.18 & 56.35 & 877.29 & 51.13 & 793.46 & 46.12 & 712.22 & 41.30 & 633.21 & 36.63 \\
\hline & \multicolumn{10}{|c|}{ Crude Protein } \\
\hline & $\mathrm{g} \mathrm{day}^{-1}$ & $\% \mathrm{MS}$ & $\mathrm{g} \mathrm{day}^{-1}$ & $\% \mathrm{MS}$ & $\mathrm{g} \mathrm{day}^{-1}$ & $\% \mathrm{MS}$ & $\mathrm{g} \mathrm{day}^{-1}$ & $\% \mathrm{MS}$ & $\mathrm{g} \mathrm{day}^{-1}$ & $\% \mathrm{MS}$ \\
\hline 0.5 & 793.35 & 12.21 & 822.23 & 11.07 & 850.09 & 10.20 & 877.10 & 9.53 & 903.36 & 8.98 \\
\hline 1.0 & 1253.61 & 17.29 & 1270.55 & 15.52 & 1286.89 & 14.16 & 1302.72 & 13.08 & 1318.13 & 12.19 \\
\hline 1.5 & 1711.14 & 19.18 & 1715.80 & 17.41 & 1720.29 & 15.99 & 1724.65 & 14.83 & 1728.88 & 13.85 \\
\hline
\end{tabular}

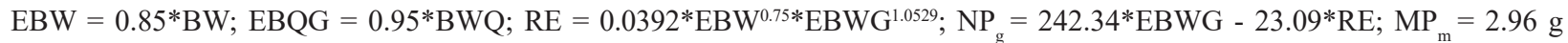
$\mathrm{EBW}^{-0.75}$ day $^{-1}$; efficiency of metabolizable protein for weight gain $=25.8 \%$; DMI $=-0.9689+0.1058 * \mathrm{BW}^{0.75}-1.2399 * \mathrm{BWG}+$ $1.8329 * \mathrm{BWG}^{2} ; \mathrm{RDP}=(120 * \mathrm{TDN}$ intake $) * 1.11 ; \mathrm{RUP}=[(\mathrm{MP}-((120 * \mathrm{TDN}$ intake*0.64) $] / 0.80 ; \mathrm{EBW}=$ empty body weight, $\mathrm{BW}=$ body weight, $\mathrm{EBWG}=$ empty body weight gain; $\mathrm{BWG}=$ body weight gain; RE = retained energy; $\mathrm{NPg}=$ net protein requirement for gain; $\mathrm{MPm}=$ metabolizable protein requirement for maintenance; DMI = dry matter intake; TDN = total digestible nutrients, $\mathrm{RDP}=$ rumen degradable protein, $\mathrm{RUP}=$ rumen undegradable protein; $\mathrm{MP}=$ total (maintenance + gain) metabolizable protein requirement. 
Based on the data described in Table 6, it was estimated that RDP supplies $62.44 \%$ of the total $\mathrm{CP}$ requirements of a dairy crossbred bull with 450 $\mathrm{kg}$ of BW and $1 \mathrm{~kg}^{\mathrm{Bay}}{ }^{-1}$ of BWG, which is lower compared with the value found by Valadares Filho et al. (2010) for Nellore purebreds (66.40\%) and crossbreds (69.98) and by Souza et al. (2012b) for Nellore purebred heifers and Nellore x Angus and Nellore x Simmental crossbred heifers (85.88\%). Silva et al. (2002) performed a joint analysis of the results of 14 studies conducted in Brazil. The results showed the use of a diet with $72 \%$ of TDN and assuming the DMI is $2.4 \%$ of BW and $1 \mathrm{~kg}$ of BWG per day, the supply of RDP to Zebu and Holstein cattle weighing $400 \mathrm{~kg}$ or greater was sufficient to meet the total $\mathrm{CP}$ requirements. However, relative to crossbreds, that pattern was found only after they attained $450 \mathrm{~kg}$ of BW, which corroborates the results of the present study, which used crossbreds.

Therefore, the equations, $\mathrm{RE}=$

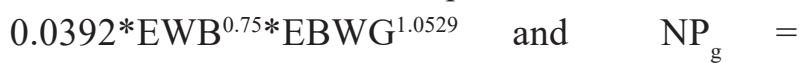
$242.34 * E B W G$ - 23.09*RE, are recommended to predict the daily net energy and protein requirements for gain, respectively. The net and metabolizable energy requirements for maintenance were estimated at 86.49 and $138 \mathrm{kcal}$ $\mathrm{EBW}^{-0.75}$ day $^{-1}$, respectively; the efficiency of use of metabolizable energy for maintenance and weight gain were estimated as $62.67 \%$ and $31.67 \%$, respectively; the MP requirements for maintenance were estimated at $2.96 \mathrm{~g} \mathrm{EBW}^{-0.75} \mathrm{day}^{-1}$, and the efficiency of use of MP for weight gain was $25.8 \%$ in confined crossbred dairy bulls.

\section{Acknowledgments}

To the National Council of Scientific and Technological Council (Conselho Nacional de Desenvolvimento Científico e Tecnológico-CNPq), Brazil and the Bank of Northeastern Brazil (Banco do Nordeste do Brasil - BNB) for partially funding the study.
To the Academic Unit of Serra Talhada/Federal Rural University of Pernambuco (Universidade Federal Rural de Pernambuco - UFRPE) and the Agronomic Institute of Pernambuco (Instituto Agronômico de Pernambuco - IPA) for their support while this study was performed.

\section{References}

AGRICULTURAL AND FOOD REASERCH COUNCIL - AFRC. Energy and protein requirements of ruminants. Wallingford: CAB International, 1993. $159 \mathrm{p}$.

AGRICULTURAL RESEARCH COUNCIL - ARC. The nutrient requirements of ruminant livestock. London: Agricultural Research Council. The Gresham Press, 1980. $351 \mathrm{p}$.

ALMEIDA, V. V. S.; QUEIROZ, A. C.; SILVA, F. F.; SILVA, R. R.; OLIVEIRA, A. C.; SOUZA, D. R. Body composition and energy and protein requirements of grazing Nellore steers. Revista Brasileira de Zootecnia, Viçosa, MG, v. 38, n. 7, p. 1347-1354, 2009.

Alves, D. D.; PAUlino, M. F.; BACKES, A. A. Desempenho produtivo de bovinos Zebu e cruzados Holandês-Zebu nas fases de recria e terminação. Acta Scientiarum. Animal Sciences, Maringá, v. 26, n. 3, p. 385-391, 2004.

ANDRADE, D. K. B.; VÉRAS, A. S. C.; FERREIRA, M. A.; SANTOS, M. V. F.; MELO, W. S.; PEREIRA, K. P. Body composition and net protein and energy requirements for weight gain of crossbred dairy cattle in grazing. Revista Brasileira de Zootecnia, Viçosa, MG, v. 38, n. 4, p. 746-751, 2009.

ANDRADE, D. K. B.; VÉRAS, A. S. C.; FERREIRA, M. A.; SANTOS, M. V. F.; MELO, W. S.; SANTOS, G. R. A. Composição corporal e exigências líquidas de macrominerais para ganho de peso em bovinos 5/8 Holandês-Zebu em pastejo na Zona da Mata de Pernambuco. Revista Brasileira de Zootecnia, Viçosa, MG, v. 37, n. 5, p. 913-918, 2008.

BACKES, A. A.; PAULINO, M. F.; ALVES, D. D.; RENNÓ, L. N.; VALADARES FILHO, S. C.; LANA, R. P. Composição corporal e exigências energéticas e protéicas de bovinos mestiços leiteiros e zebu, castrados, em regime de recria e engorda. Revista Brasileira de Zootecnia, Viçosa, MG, v. 34, n. 1, p. 257-267, 2005. 
BACKES, A. A.; PAUlinO, M. F.; ALVES, D. D.; VALADARES FILHO, S. C. Tamanho relativo dos órgãos internos e do trato gastrintestinal de bovinos indubrasil e mestiços leiteiros em fase de engorda. Ciência Rural, Santa Maria, v. 40, n. 5, p. 1160-1165, 2010.

BRASIL, Ministério da Agricultura, Pecuária e Abastecimento. Instrução Normativa $\mathrm{N}^{\circ} 3$ de 17 de janeiro de 2000. Diário Oficial [da] União, Brasília, 24 jan. 2000, Seção 1. p. 14. Disponível em: <http:// sistemasweb.agricultura.gov.br/sislegis/action/ detalhaAto.do? method $=$ consultarLegislacaoFederal $>$. Acesso em: 18 mar. 2015.

CASALI, A. O.; DETMANN, E.; VALADARES FILHO, S. C.; PEREIRA, J. C.; HENRIQUES, L. T.; FREITAS, S. G.; PAULINO, M. F. Influência do tempo de incubação e do tamanho de partículas sobre os teores de compostos indigestíveis em alimentos e fezes bovinas obtidos por procedimentos in situ. Revista Brasileira de Zootecnia, Viçosa, MG, v. 37, n. 2, p. 335-342, 2008.

COSTA E SILVA, L. F.; VALADARES FILHO, S. C.; ZANETTI, D.; ROTTA, P. P.; MARCONDES, M. I.; PRADOS, L. F.; PAULINO, M. F.; AZEVEDO, H. O. Energy and protein nutritional requirements for Nellore bulls. Revista Brasileira de Zootecnia, Viçosa, MG, v. 41, n. 6, p. 1516-1524, 2012.

COSTA, D.; ABREU, J. B. R.; MOURÃO, R. C.; SILVA, J. C. G.; RODRIGUES, V. C.; SOUSA, J. C. D.; MARQUES, R. A. F. S. Características de carcaça de novilhos inteiros Nelore e F1 Nelore x Holandês. Ciência Animal Brasileira, Goiânia, v. 8, n. 4, p. 687696, 2007.

DETMANN, E.; SOUZA, M. A.; VALADARES FILHO, S. C.; QUEIROZ, A. C.; BERCHIELLI, T. T.; SAlIBA, E. O. S.; CABRAL, L. S.; PINA, D. S.; LADEIRA, M. M.; AZEVEDO, J. A. G. Métodos para análise de alimentos. Suprema: Visconde do Rio Branco, 2012. $214 \mathrm{p}$.

FERNANDES, H. J.; PAULINO, M. F.; MARTINS, R. G. R.; VALADARES FILHO, S. C.; TORRES, R. A.; PAIVA, L. M.; RIBEIRO, V. A. Crescimento de componentes corporais de três grupos genéticos na fases de recria e terminação. Revista Brasileira de Zootecnia, Viçosa, MG, v. 34, n. 1, p. 288-296, 2005.

FERRELL, C. L.; JENKINS, T. G. Body composition and energy utilization by steers of diverse genotypes fed a high-concentrate diet during the finishing period: I. Angus, Belgian Blue, Hereford, and Piedmontese Sires. Journal of Animal Science, Savoy, v. 76, n. 2, p. 637-646, 1998.
FREITAS, J. A.; QUEIROZ, A. C.; DUTRA, A. R.; VIEIRA, R. A. M.; LANA, R. P.; LEONEL, F. P.; HENRIQUE, D. S.; LIMA, A. V.; SOUZA. J. C. Composição do ganho e exigências de energia e proteína para ganho de peso em bovinos Nelore puros e mestiços. Revista Brasileira de Zootecnia, Viçosa, MG, v. 35, n. 3, p. 886-893, 2006.

FULLER, W. A. Measurement error models. New York: John Wiley and Sons, New York, 1987. 440 p.

HALL, M. B. Calculation of non-structural carbohydrate content of feeds that contain non-protein nitrogen. Gainesville: University of Florida, 2000. A-25 p. (Bulletin, 339).

LOFGREEN, G. P.; GARRETT, W. N. A system for expressing net energy requirements and feed values for growing and finishing beef cattle. Journal of Animal Science, Savoy, v. 27, n. 3, p. 793-806, 1968.

MARCONDES, M. I.; VALADARES FILHO, S. C.; OLIVEIRA, I. M.; PAULINO, M. F.; PAULINO, P. V. R.; DETMANN, E.; SILVA, L. F. C. Exigências de energia de animais Nelore puros e mestiços com as raças Angus e Simental. Revista Brasileira de Zootecnia, Viçosa, MG, v. 40, n. 4, p. 872-881, 2011a.

MARCONDES, M. I.; VALADARES FILHO, S. C.; OLIVEIRA, I. M.; VALADARES, R. F. D.; PAULINO, M. F.; PRADOS, L. F. Exigências de proteína de animais Nelore puros e cruzados com as raças Angus e Simental. Revista Brasileira de Zootecnia, Viçosa, MG, v. 4, n. 10, p. 2235-2243, 2011b.

NASCIMENTO, P. V. N.; SILVA, F. F.; VELOSO, C. M.; BONOMO, P.; TEIXEIRA, F. A.; GONSALVES NETO, J. Exigências nutricionais de bezerros da raça Holandesa alimentados com concentrado e feno de capim-elefante. Revista Brasileira de Zootecnia, Viçosa, MG, v. 38, n. 8, p. 1605-1613, 2009.

NATIONAL RESEARCH COUNCIL - NRC. Nutrient requirements of beef cattle. $7^{\text {th }}$ ed. Washington, D.C.: National Academy Press, 2000. 242 p.

NEVES, M. L. M. W. Exigências nutricionais e componentes não carcaça de bovinos mestiços leiteiros. 2013. Tese (Doutorado em Zootecnia) - Universidade Federal Rural de Pernambuco, Recife.

PORTO, M. O.; PAULINO, M. F.; VALADARES FILHO, S. C.; DETMANN, E.; CAVALI, J.; SALES, M. F. L.; VALENTE, E. E. L.; COUTO, V. R. M. Nutritional requirements of energy, protein and macrominerals for maintenance and weight gain of young crossbred Nellore $\times$ Holstein bulls on pasture. Revista Brasileira de Zootecnia, Viçosa, MG, v. 41, n. 3, p. 734-745, 2012. 
PRADOS, L. F. Desempenho e exigências nutricionais de bovinos alimentados com dietas contendo diferentes níveis de cálcio e fósforo. 2012. Dissertação (Mestrado em Zootecnia) - Universidade Federal de Viçosa, Viçosa, MG.

ROTTA, P. P.; VALADARES FILHO, S. C.; DETMANN, E.; COSTA E SILVA, L. F.; VILLADIEGO, F. A. C.; BURGOS, E. M. G.; SILVA, F. A. S. Nutrient requirements of energy and protein for Holstein $\times$ Zebu bulls finished in feedlot. Semina: Ciências Agrárias, Londrina, v. 34, n. 5, p. 2523-2534, 2013.

SILVA, F. F.; VALADARES FILHO, S. C.; ÍTAVO, L. C. V.; VELOSO, C. M.; VALADARES, R. F. D.; CECON, P. R.; PAULINO, P. V. R.; MORAES, E. H. B. $\mathrm{K}$. Exigências líquidas e dietéticas de energia, proteína e macroelementos minerais de bovinos de corte no Brasil. Revista Brasileira de Zootecnia, Viçosa, MG, v. 31, n. 2, p. 776-792, 2002.

SILVA, G. S. Desempenho e rendimento de carcaça de novilhos mestiços leiteiros submetidos a dietas com diferentes niveis de concentrado. 2012. Dissertação (Mestrado em Zootecnia) - Universidade Federal Rural de Pernambuco, Recife.

SIQUEIRA, J. G.; FONTES, C. A. A.; PEREIRA, A. L.; LOMBARDI, C. T.; SANT'ANA, N. F.; VIEIRA, R. A. M. Exigência de energia de mantença e composição corporal e do ganho de vacas de corte adultas de três grupos genéticos confinadas. Revista Brasileira de Zootecnia, Viçosa, MG, v. 36, n. 6, p. 2159-2167, 2007. Suplemento.

SNIFFEN, C. J.; O'CONNOR, J. D.; VAN SOEST, P. J.; FOX, D. G.; RUSSELL, J. B. A net carbohydrate and protein system for evaluating cattle diets: II.
Carbohydrate and protein availability. Journal of Animal Science, Savoy, v 70, n. 11, p. 3562-3577, 1992.

SOUZA, E. J. O.; VALADARES FILHO, S. C.; GUIM, A.; VALADARES, R. F. D.; MARCONDES, M. I.; FERREIRA, M. A.; PRADOS, L. F.; BENEDETI, P. D. B. Protein requirements for females of Nellore, Nellore $\times$ Angus and Nellore $\times$ Simmental fed on two forage:concentrate ratios. Revista Brasileira de Zootecnia, Viçosa, MG, v. 41, n. 3, p. 762-770, 2012 b.

SOUZA, E. J. O.; VALADARES FILHO, S. C.; GUIM, A,; VALADARES, R. F. D.; MARCONDES, M. I.; VÉRAS, A. S. C.; AMARAL, P. M.; SANTOS, T. R. Energy nutritional requirements for females of Nellore, Nellore $\times$ Angus and Nellore $\times$ Simmental fed on two forage:concentrate ratios. Revista Brasileira de Zootecnia, Viçosa, MG, v. 41, n. 3, p. 753-761, 2012a.

VALADARES FILHO, S. C.; MARCONDES, M. I.; CHIZZOTTI, M. L.; PAULINO, P. V. R. Exigências nutricionais de zebuinos puros e cruzados - BR CORTE. 2. ed. Viçosa, MG: UFV, Suprema Gráfica Ltda, 2010. $193 \mathrm{p}$.

VALADARES FILHO, S. C.; PAULINO, P. V. R.; MAGALHÃES, K. A. Exigências nutricionais de zebuínos e tabelas de composição de alimentos - BR CORTE. Viçosa, MG: UFV, Suprema Gráfica Ltda, 2006. $142 \mathrm{p}$.

ZERVOUDAKIS, J. T.; PAULINO, M. F.; DETMANN, E.; VALADARES FILHO, S. C.; LANA, R. P.; CECON, P. R.; QUEIROZ, D. S.; MOREIRA, A. L. Conteúdo corporal e exigências líquidas de proteína e energia de novilhos suplementados no período das águas. Revista Brasileira de Zootecnia, Viçosa, MG, v. 31, n. 1, p. 530537, 2002. 